\title{
A Geospatial Assessment of Small-Scale Hydropower Potential in Sub-Saharan Africa
}

\author{
Alexandros Korkovelos 1,*(D), Dimitrios Mentis ${ }^{1,2}$, Shahid Hussain Siyal ${ }^{1}$, \\ Christopher Arderne ${ }^{3}$, Holger Rogner ${ }^{1,4}$, Morgan Bazilian 1,5, Mark Howells ${ }^{1}$, Hylke Beck ${ }^{6}$ (D) \\ and Ad De Roo ${ }^{7}$ \\ 1 Division of Energy System Analysis, KTH Royal Institute of Technology, 11428 Stockholm, Sweden; \\ dimitrios.mentis@wri.org (D.M.); siyal@kth.se (S.H.S.); holger.rogner@gmail.com or \\ rogner@iiasa.ac.at (H.R.); mbazilian@mines.edu (M.B.); mark.howells@energy.kth.se (M.H.) \\ 2 World Resources Institute, Washington, DC 20002, USA \\ 3 The World Bank Group, Washington, DC 20433, USA; carderne@worldbank.org \\ 4 International Institute for Applied Systems Analysis (IIASA), A-2361 Laxenburg, Austria \\ 5 Colorado School of Mines, Golden, CO 80401, USA \\ 6 Civil and Environmental Engineering, Princeton University, Princeton, NJ 08544, USA; \\ hylke.beck@gmail.com \\ 7 European Union Joint Research Centre (EU-JRC), 21027 Ispra, VA, Italy; Ad.DE-ROO@ec.europa.eu \\ * Correspondence: alekor@kth.se; Tel.: +46-(0)735-84-36-13
}

Received: 15 October 2018; Accepted: 6 November 2018; Published: 9 November 2018

\begin{abstract}
Sub-Saharan Africa has been at the epicenter of an ongoing global dialogue around the issue of energy poverty. More than half of the world's population without access to modern energy services lives there. It also happens to be a sub-continent with plentiful renewable energy resource potential. Hydropower is one of them, and to a large extent it remains untapped. This study focuses on the technical assessment of small-scale hydropower (0.01-10 MW) in Sub-Saharan Africa. The underlying methodology was based on open source geospatial datasets, whose combination allowed a consistent evaluation of $712,615 \mathrm{~km}$ of river network spanning over 44 countries. Environmental, topological, and social constraints were included in the form of constraints in the optimization algorithm. The results are presented on a country and power pool basis.
\end{abstract}

Keywords: hydropower; Sub-Saharan Africa; geographic information systems; electrification

\section{Introduction}

Electricity holds a privileged place in modern societies as it literally powers opportunities for socioeconomic development and well-being [1]. Yet it is estimated globally that about 1 billion people lack access to electricity [2,3]. The Agenda for Sustainable Development, launched by the UN in 2015, envisions universal access to modern energy services by 2030 [4]. Taking into account the current access deficit and population growth projections, it is estimated that the population to be electrified by 2030 surpasses 2.5 billion people worldwide [2].

In Sub-Saharan Africa (SSA), it is estimated that more than 620 million people do not have access to electricity services, while nearly 730 million people rely on traditional fuels (firewood and charcoal) in order to cover their daily energy needs (cooking, lighting, etc.) [2,5]. A majority of this population is located in rural areas, far away from the existing, usually poorly developed grid network. Electrifying these areas is a challenging process and usually requires significant investments and technological and structural changes in energy systems [6,7]. In order to maximize impact, not only do public and private investments towards providing access need to dramatically increase, but they need to be deployed in a cost-effective way $[2,8]$. 
Recent studies indicate that the decentralization (typically of a scale less than $10 \mathrm{MW}$ ) of energy systems can help in addressing energy poverty [9-14]. Off-grid or mini-grid systems can be a viable near-term alternative to grid extension in many parts of Sub-Saharan Africa [15]. The prospect for decentralized energy supplies are further enhanced by the continent's abundant renewable resources. Further, the local employment is developed for deployment and maintenance of local renewable electricity generating equipment [5]. A cornerstone in the movement towards renewables is hydropower $[16,17]$.

\subsection{Role of Hydropower}

Hydropower is a technically mature and economically competitive renewable energy source that can provide significant advantages in the operations and stability of energy systems [16]. Across Africa, hydropower is responsible for $74.2 \%$ of all non-fossil fuel electricity use [18]. In 2017 the total installed hydropower capacity in Africa was $35.34 \mathrm{GW}$ [16], producing approximately $131 \mathrm{TWh}$ of electricity; hydropower accounts for about $21 \%$ of the total installed capacity in the continent $[16,18,19]$. Focusing on Sub-Saharan Africa, the installed hydropower capacity (as in 2017) was estimated at 30.4 GW [16]. Despite this, around $92 \%$ of the $300 \mathrm{GW}$ potential still remains untapped [20].

The opportunities for expanding hydropower are considerable and could help support electricity provision in remote African communities, especially when developed in a small, decentralized scale [21,22]. Given favorable hydrological conditions, hydropower offers a relatively low levelized cost, continuous generation without storage requirements, and the ability to operate both in isolated or interconnected (to a national grid) mode [23]. It is estimated that the installed capacity of small-scale hydropower (below $10 \mathrm{MW}$ ) in Sub-Saharan Africa surpasses $476 \mathrm{MW}[24,25]$.

According to [21,24], the small-scale hydropower resource potential in the region is estimated at 12,197 MW, with the eastern part of the continent showing the highest potential. Szabo et al. [9] consider small-scale hydro as a very suitable option for rural electrification in Africa, showing high potential for deployment in the central and south-most eastern parts of the continent. Furthermore, high levels of hydro-deployment are expected over the next 20 years in part due to its noticeable potential for emission reduction compared to fossil fuel alternatives [26]. Other studies also suggest the inclusion of small-scale hydropower in the development of national electrification plans in Sub-Saharan Africa $[2,10,11,27]$.

\subsection{Scope of the Study}

Energy planning activities depend strongly on reliable and consistent energy resource assessments [28]. So far, regional estimates of hydropower potential have been based on data aggregation [29-32] with varying levels of accuracy [21], inevitably resulting in significant discrepancies and inconsistencies between the data and collection methods. Improving the quality and consistency of hydropower potential assessments is a prerequisite for the implementation of sustainable energy supplies in Sub-Saharan Africa [33]. In addition to that, the addition of a geo-spatial component in such assessments can help answering questions regarding proper site selection and lead to better allocation of (usually) scarce financial resources.

Geographic Information Systems (GIS) and modern remote sensing techniques convey useful information that can add significant value in hydropower assessments. Their integration can provide useful insights to policy makers and developers regarding the future deployment and spatial distribution of distributed generation systems, including among them new hydropower plants [20].

There is a significant number of studies that assess the potential of hydropower using GIS based approaches [31,34-47]. The majority of these studies however, are focused on a particular hydrological unit (basin, sub-basin) or on a country level. An exception is the study carried out by Zhou et al., which assesses the potential for hydro-generated electricity on a global scale, but does not spatially identify the locations of potential sites for hydropower exploitation. Furthermore, the analysis has been 
conducted on a $0.5 \times 0.5$ degree basis, a coarse resolution that increases uncertainty when interpreting the results [20].

This study aims to address the previously described data limitations by providing a comprehensive geospatial assessment of hydropower potential at regional level and high spatial resolution (0.00083 degrees, $\sim 100 \mathrm{~m}$ ) for 44 countries in Sub-Saharan Africa. This study focuses on small-scale hydropower in particular, since big hydropower plants (GERD (Grand Ethiopian Renaissance Dam), Grand Inga, Akosombo, Kariba, Cahora Bassa, Gibe, Merowe etc.) have long been identified in the region and are often already operational [5,16,25,48,49].

Small-scale hydropower definition varies between countries with the upper capacity limit ranging from $1 \mathrm{MW}$ to $50 \mathrm{MW}$ [24]. In this study we consider capacities from 0.1 to $10 \mathrm{MW}$ with the range from 0.1-1 MW referred to as "mini" and from 1.01 to $10 \mathrm{MW}$ referred to as "small" hydropower.

\section{Material and Methods}

\subsection{Study Area}

This study focuses on Sub-Saharan Africa. In total, 44 countries were taken into consideration (Table A1 in Appendix A) covering a total area of 26.5 million $\mathrm{km}^{2}$ (Figure 1).

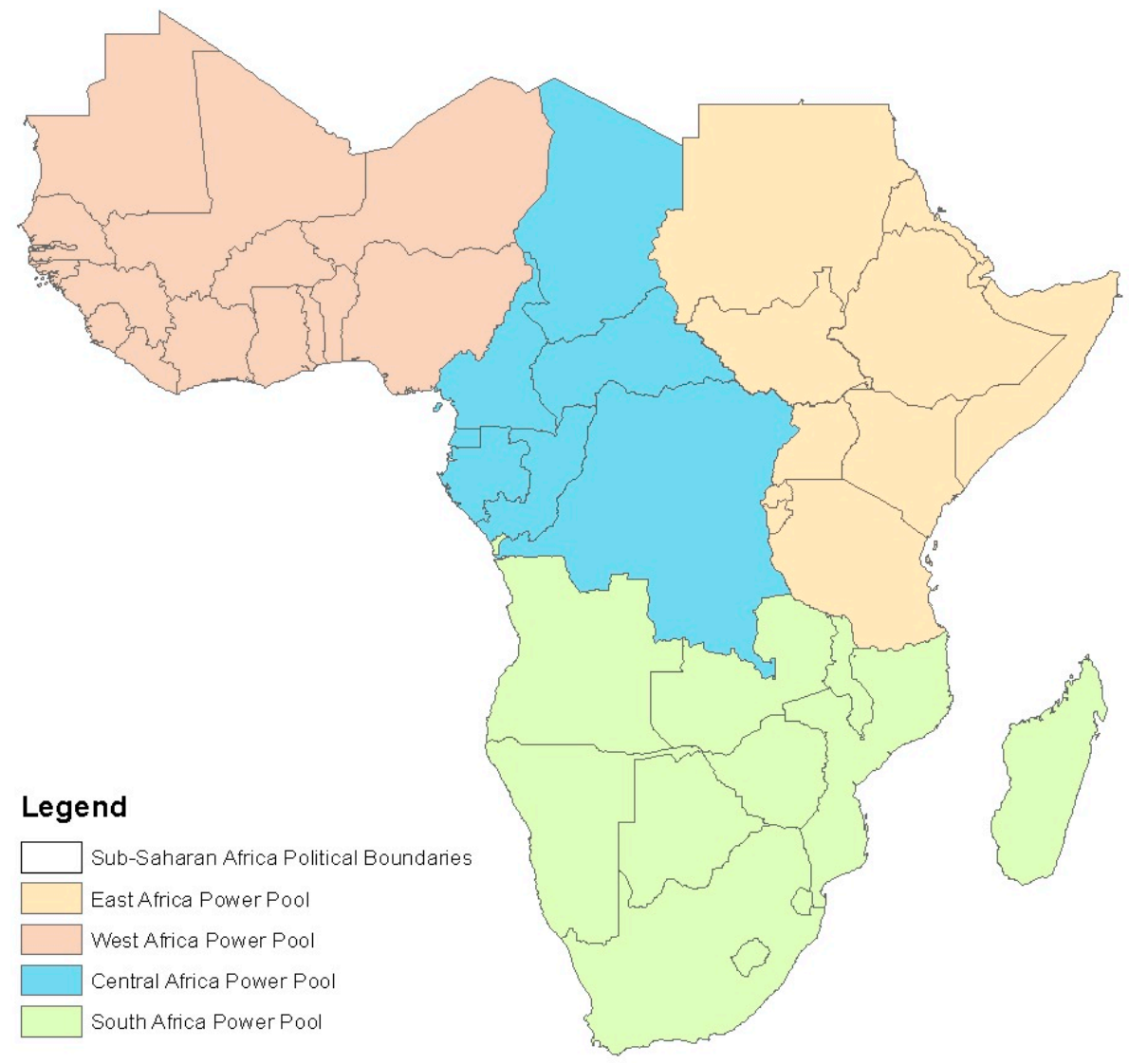

Figure 1. Political administrative boundaries in Sub-Saharan Africa and country classification per power pool [50].

The topological characteristics vary significantly over the study area with higher elevation fluctuations in the eastern and southern parts and a progressive diminution in altitude towards the western and northern parts. To a great extent, Sub-Saharan Africa is characterized by a hot climate (mostly equatorial, tropical savannah, humid subtropical) with a variable temperature range $\left(15-35{ }^{\circ} \mathrm{C}\right)$ and considerable precipitation levels $(800-3200 \mathrm{~mm} /$ year) throughout the year [51]. Freshwater resources are estimated at 3931 billion $\mathrm{m}^{3}$ per year (approx. $9 \%$ of world's resources) with 
higher availability in the central part of the sub-continent [52]. In total, 712,615 km of perennial river networks have been identified and used in this study [53].

\subsection{Methodology}

The methodology can be divided into four main steps. The first, considers the acquisition and calibration of all the input GIS datasets so as to retrieve essential information that can be used in the assessment. The second step considers the calculation of the hydropower potential in each location; the third step involves the selection process of suitable sites based on technical and topological criteria. Finally, the forth step considers analysis of the results and visualization. Figure 2 schematically represents these steps:

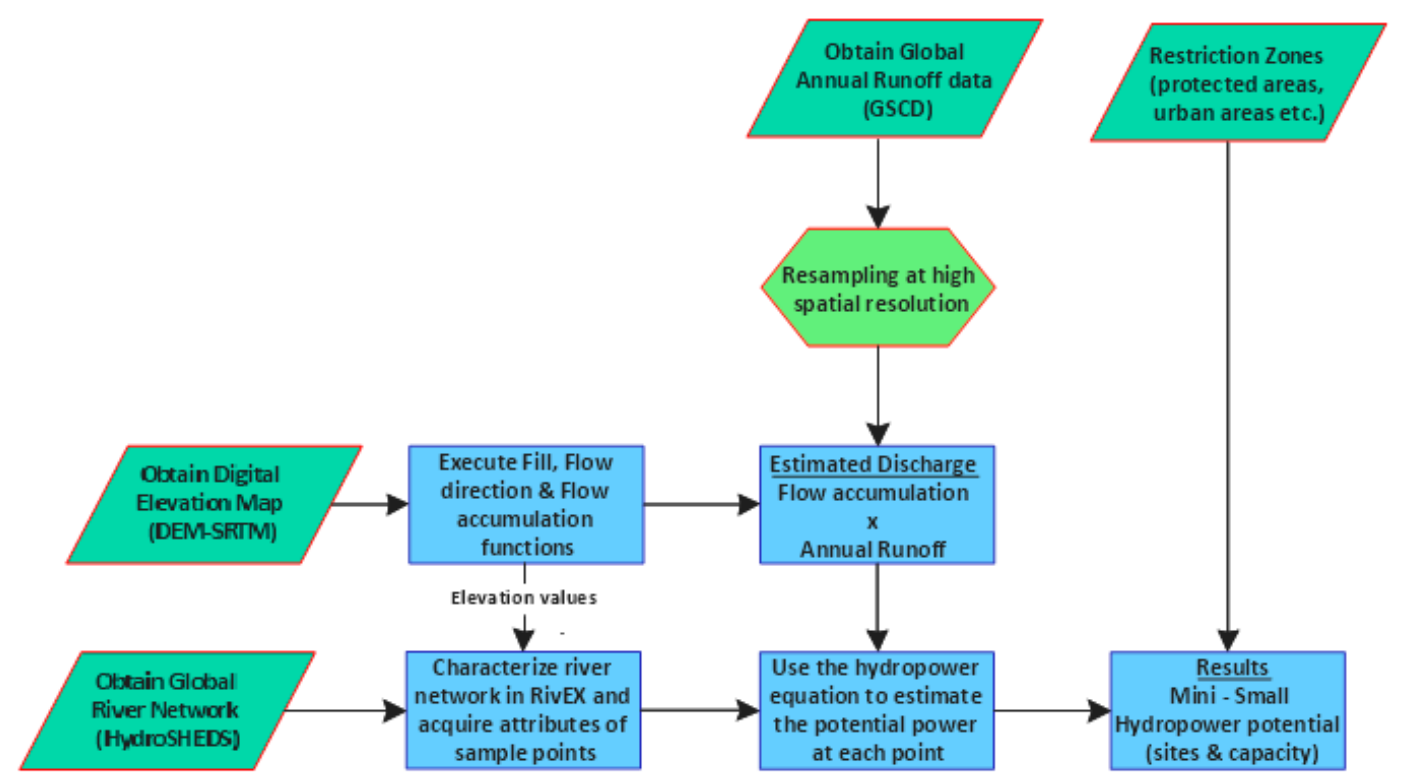

Figure 2. Small-scale hydropower assessment methodology flowchart.

\subsection{Input GIS Data}

The first step of the methodology considers the use of various GIS layers, whose attributes were correlated, combined and analyzed in order to retrieve the required information and allow the assessment of mini and small hydropower technical potential in all identified rivers. Table 1 presents the GIS datasets that set the basis of this assessment.

Table 1. List of Geographic Information Systems (GIS) datasets used for the mini-small hydropower assessment in Sub-Saharan Africa.

\begin{tabular}{ccc}
\hline Dataset & Type & Source \\
\hline Digital Elevation Map (DEM-SRTM) & Raster & {$[54]$} \\
Global River Network (HydroSHEDS) & Vector (Polyline) & {$[53]$} \\
Global Streamflow Characteristics Dataset (GSCD) & Raster & {$[55,56]$} \\
Administrative Boundaries & Vector (Polygon) & {$[50]$} \\
Restriction Zones & Raster-Vector & {$[57-59]$} \\
\hline
\end{tabular}

First, digital elevation models (DEM) at 0.00083 degrees spatial resolution were obtained by the NASA/JPL Shuttle Radar Topography Mission (SRTM) [54]. The layers were collected in five-degree tiles and merged using a common GIS routine in order to obtain an aggregated elevation map of regional coverage for land surfaces; the maps included latitudes between 40 degrees North and 35 degrees South and longitudes between 20 degrees West and 55 degrees East. 
The product elevation map was then further processed using the "Hydrology" toolbox in ArcGIS. More specifically, the "Flow Direction" and "Flow Accumulation" tools were used. Surface elevation values were used as inputs in order to produce two raster layers; one showing the direction of stream flow for each individual cell and another showing the cumulative number of upstream cells arriving at each node. Knowing the spatial resolution of the accumulation flow raster layer (0.00083 degrees), an estimated value of the catchment area for each location was obtained.

In parallel, the global annual mean runoff raster layer was retrieved from the Global Streamflow Characteristics Dataset (GSCD) provided by the European Joint Research Centre (EU-JRC) [55,56]. The map was available at a spatial resolution of 0.125 degrees (approx. $15 \mathrm{~km}$ at the equator) and was resampled to 0.00083 degrees using bilinear interpolation. Next, the flow accumulation raster layer was combined with the resampled mean annual runoff raster layer in order to obtain an estimate of the average discharge $\left(\mathrm{m}^{3} / \mathrm{s}\right)$ value for each individual cell/location. At a resolution of 0.00083 degrees this yielded a layer of $\sim 2.9$ billion grid cells for all Sub-Saharan Africa.

In order to eliminate any erroneous stream flows, the HydroSHEDS river network for Sub-Saharan Africa was used in a form of a vector layer at 0.00415 degrees (approx. $500 \mathrm{~m}$ at the equator) [53]. The river network was processed in ArcGIS with the use of a programming routine developed in Python. Each uniquely identified stream was assigned a source point, a mouth point and several $1 \mathrm{~km}$ segments along its length. The sequential flow and connectivity of the streams were also calculated and assigned as attribute. This process yielded $712,615 \mathrm{~km}$ of river network spanning over 44 countries in the sub-continent.

\subsection{Discharge Quality Assessment}

GIS practices usually rely on the combination of layers with various temporal-spatial resolutions and geographic projections. This is likely to cause spatial distortion adversely affecting the quality and accuracy of the results. This study is no exception. Processing geospatially thousands of potential hydropower sites over 26.5 million $\mathrm{km}^{2}$, was a considerably challenging task. When working at this geographical extent the spatial resolution of the input layers can be a critical source of uncertainty. Lower resolution facilitates data processing but induces rough geographical assumptions; the opposite applies to higher resolution layers. While this applies to all layers, the quality of the discharge layer was of particular interest in this study as it has a high impact on the results. Therefore, a more elaborate view was taken involving the comparison of two different layers.

The first layer (hereafter DEM-GSCD) was developed by combining attributes from the DEM and GSCD layers as described in a previous paragraph. In the context of the studied area (Sub-Saharan Africa), this dataset yielded discharge values for $\sim 2.9$ billion grid cells; each cell representing a location spanning over $\sim 0.009 \mathrm{~km}^{2}$.

The second layer was retrieved from the Distributed Water Balance and Flood Simulation Model (hereafter LISFLOOD) for Africa, developed by the European Commission Joint Research Centre (EU-JRC) [60]. This layer provided simulated daily discharge values at 0.1-degree spatial resolution for a 34-year period (1979-2012). Daily data were first aggregated to monthly averages and thereafter to total annual averages in order to fit the objective of this study. In this case, the output included discharge values for $\sim 2.2$ million grid cells; each cell representing a location spanning over $\sim 12 \mathrm{~km}^{2}$.

In order to test the two discharge layers (DEM-GSCD and LISFLOOD) against actual data, we extracted their values and compared with historical measurements from 1393 gauged stations [61]. The stations spanned across 40 countries in Sub-Saharan Africa, as seen in Figure 3. The comparison was based on two indices (1) the Pearson's correlation coefficient (r) which indicates the degree of linear relationship between the observed and simulated data and ranges from -1 to 1 (implying a perfect negative or positive linear relationship) and (2) the coefficient of determination $\left(R^{2}\right)$ which describes the proportion of the error variance between the simulated and observed data. $R^{2}$ ranges from 0 to 1 , with higher values indicating less error variance, and typically with values greater than 0.5 being acceptable $[62,63]$. 


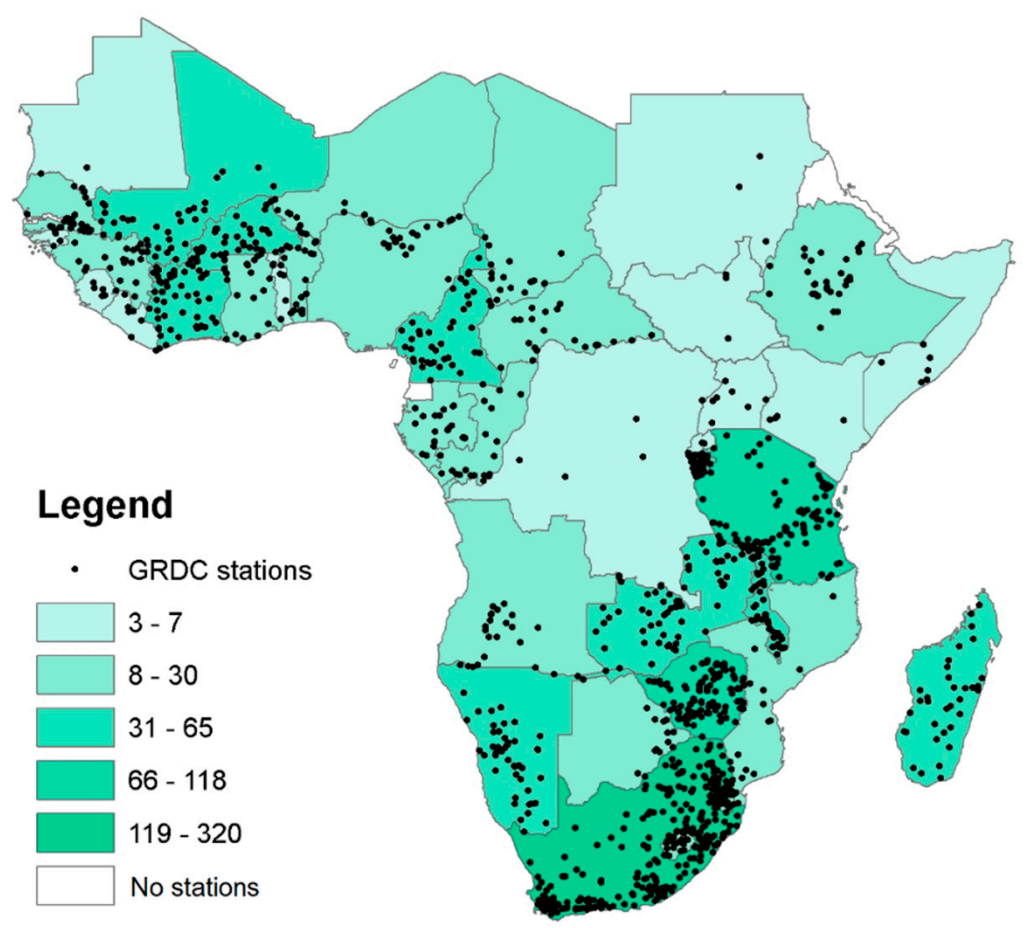

Figure 3. Spatial distribution of Global Runoff Data Center [61] stations across the studied region [50].

\subsubsection{Assessment of the DEM-GSCD Discharge Layer}

Each gauged location (represented as vector point) was assigned a discharge value from the DEM-GSCD layer; the assignment was based on a common GIS routine (extracting values from a raster layer to points). An overlapping moving maximum filter was also applied in order to identify the maximum value within a neighborhood of $500 \mathrm{~m}$.

The analysis between the measured and simulated discharge values showed a Pearson's correlation coefficient $(r)$ of 0.776 and a coefficient of determination $\left(R^{2}\right)$ of 0.602 , indicating a positive linear relationship (Figure 4) between the two sets and an acceptable error variance. About $98.6 \%$ of the 1393 locations were assigned a discharge value from the DEM-GSCD layer, whereas for the rest $1.4 \%$ no value index (-9999) was returned, most probably due to inaccuracies in the simulated layer. For $67.5 \%$ of the locations, the actual discharge value fell within a $\pm 10 \%$ range from the simulated discharge layer, while $7.8 \%$ showed a significant difference. This difference, however, was observed in big river gauges with high flow fluctuation throughout the year. By excluding measurement points with discharge higher than $100 \mathrm{~m}^{3} / \mathrm{s}$ (typically, out of the range of small run-off-river hydropower [64]), the success rate (values within the identified $\pm 10 \%$ range) increased to $73.4 \%$. This result can be explained by the fact that the GSCD was derived from small catchment areas $\left(<10,000 \mathrm{~km}^{2}\right)$ [56] making it more representative for smaller flow rivers.

\subsubsection{Assessment of the LISFLOOD Discharge Layer}

Discharge values from the LISFLOOD layer were assigned to each location using a similar GIS routine. In this case, the correlation analysis between measured and simulated discharge values yielded an $r$ value of 0.524 and an $R^{2}$ value of 0.274 , implying a weak linear relationship and a non-acceptable error variance (Figure 5). 


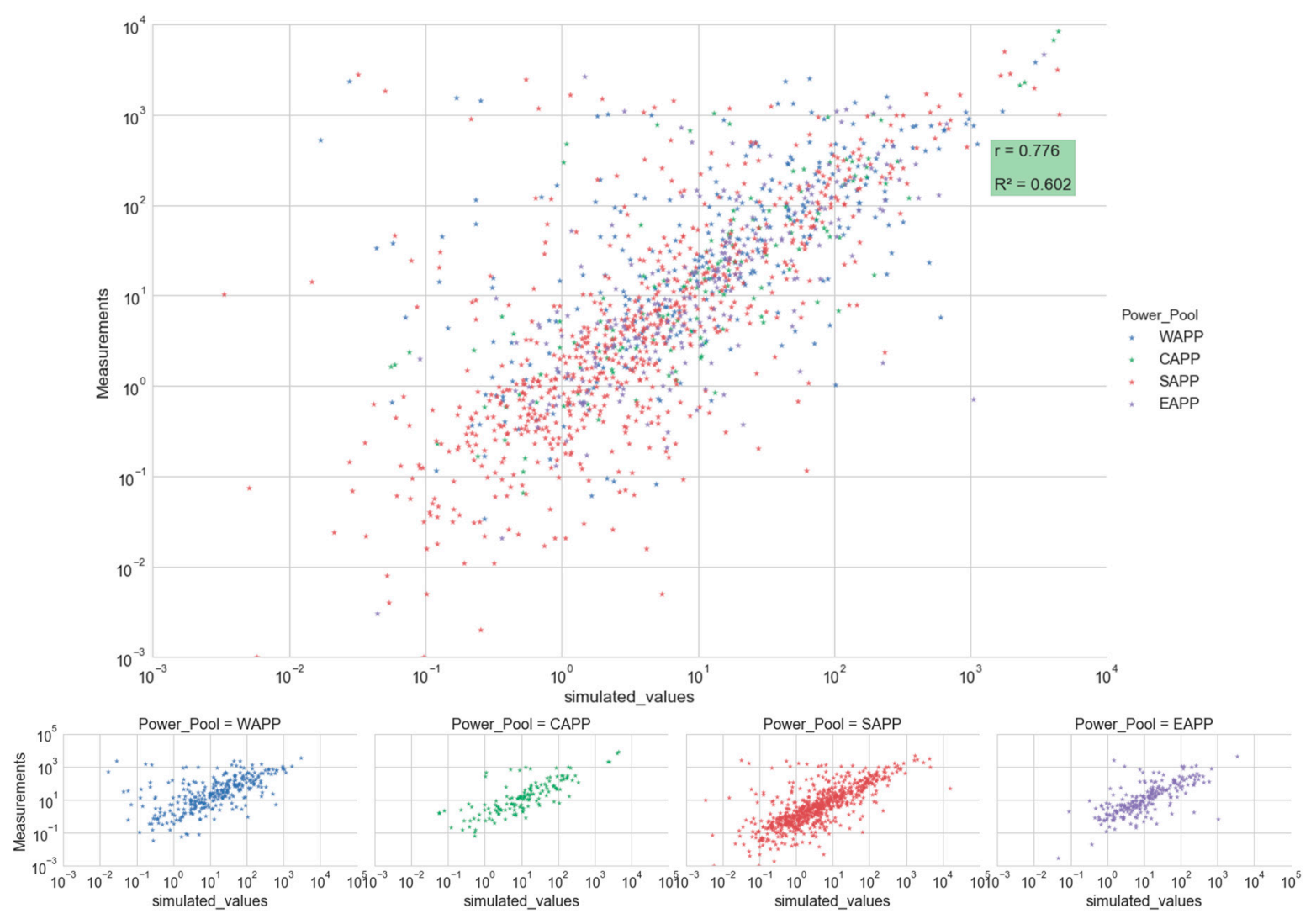

Figure 4. Observed (GRDC measurements) vs. simulated (DEM-GSCD) scatter plots; aggregated (above) and by power pool (below); values are in $\mathrm{m}^{3} / \mathrm{s}$.

In this case, $92.8 \%$ of the 1393 locations were successfully assigned a discharge value from the LISFLOOD layer. The lower rate (than in the previous case) is possibly attributed to inaccuracies of the GIS layer and/or the selected assignment process. In this case, $80.5 \%$ of the locations fell within a $\pm 10 \%$ range from the simulated discharge layer, while $2.6 \%$ showed a significant difference. This was particularly evident in small flows $\left(<1 \mathrm{~m}^{3} / \mathrm{s}\right)$. In contrary to the previous case by eliminating high discharge value points, the rate of measurements within limits decreased to $80.3 \%$; that is, the LISFLOOD layer better captured higher discharge values, thus more representative for higher flow rivers.

\subsubsection{Comparison and Assessment}

Table 2 provides a summary of the statistical indicators compared between the two tested discharge layers for Sub-Saharan Africa. In essence, the DEM-GSCD dataset displayed a higher level of correlation for smaller flow rivers, thus serving better the objectives of this study, focusing on small-scale hydropower. Please note that these results do not indicate by any means that the LISFLOOD layer is erroneous. The difference between LISFLOOD and DEM-GSCD may also reflect the variance in the quality of the precipitation data employed to obtain the discharge estimates. LISFLOOD was driven using the WATCH Forcing Data methodology applied to ERA-Interim (WFDEI) dataset [65] while the GSCD was derived from WorldClim [66]. Compared to WFDEI, WorldClim incorporates considerably more actually measured data. Furthermore, the results may have also been affected by the layers' initial spatial resolution and/or the resampling process followed. 

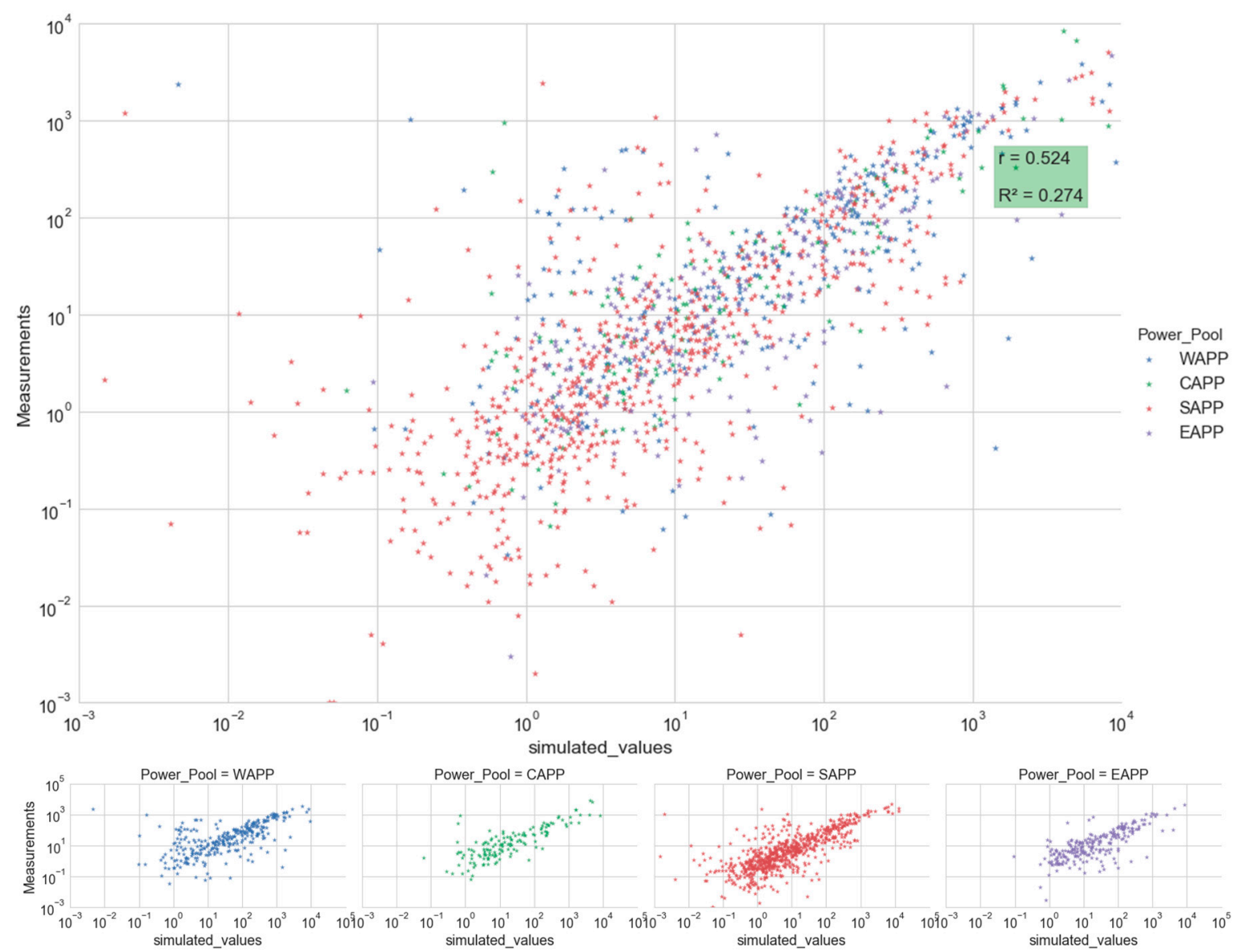

Figure 5. Observed (GRDC measurements) vs. simulated (LISFLOOD) scatter plots; aggregated (above) and by power pool (below); values are in $\mathrm{m}^{3} / \mathrm{s}$.

Table 2. Performance assessment of the two simulated discharge layers.

\begin{tabular}{|c|c|c|c|c|c|c|}
\hline \multirow{2}{*}{$\begin{array}{l}\text { Source of } \\
\text { Discharge } \\
\text { Layer }\end{array}$} & \multirow{2}{*}{$\begin{array}{c}\text { Spatial } \\
\text { Resolution } \\
\text { (Degrees) }\end{array}$} & \multirow{2}{*}{$\begin{array}{l}\text { Available } \\
\text { Time } \\
\text { Resolution }\end{array}$} & \multicolumn{2}{|c|}{$\begin{array}{l}\text { Successful Value Assignment to } 1393 \\
\text { Measurement Points (Gauged Stations) }\end{array}$} & \multirow{2}{*}{$\begin{array}{l}\text { Pearson's } \\
\text { Correlation } \\
\text { Coefficient (r) }\end{array}$} & \multirow{2}{*}{$\begin{array}{c}\text { Coefficient of } \\
\text { Determination }\left(R^{2}\right)\end{array}$} \\
\hline & & & $\begin{array}{c}\text { Over All } \\
\text { Stations (\%) }\end{array}$ & $\begin{array}{c}\text { Simulated Values } \\
\text { within } \pm 10 \% \text { from } \\
\text { Observed Values }(\%)\end{array}$ & & \\
\hline $\mathrm{DEM}+\mathrm{GSDC}$ & 0.00083 & Yearly average & 98.6 & 73.4 & 0.776 & 0.602 \\
\hline LISFLOOD & 0.1 & $\begin{array}{l}\text { Daily values } \\
(1999-2000)\end{array}$ & 92.8 & 80.3 & 0.524 & 0.274 \\
\hline
\end{tabular}

\subsection{Estimating Hydropower Potential}

The suggested methodology aimed at estimating small-scale (0.1 to $10 \mathrm{MW}$ ) [64] hydropower potential. For simplification, we focus only on diversion (run-off-river) type power plants operating with impulsive turbine (e.g., Pelton) and no storage; this type of hydropower plants are more suitable for applications with high head and relatively low volume flow; they are simple and can be deployed fast (no dam required) and are quite common for small-scale applications [67].

The assessment at each site was conducted by combining two main components, the potential head, and the estimated discharge value. The head was assessed based on the elevation difference (derived from DEM) between the selected point and its closest upstream neighbor, which in this case was located at a distance of $1 \mathrm{~km}$. The discharge value was extracted from the discharge raster layer described in the previous section. This way, it was ensured that the points on the river network picked up the correct discharge, and not an erroneously low discharge value from either side of the actual 
river. Subsequently, the potential power was estimated using the hydropower equation, as shown below [68]:

$$
P_{p}=\rho \times g \times n_{t} \times n_{g} \times c \times \dot{Q} \times\left(H_{p . u p}-H_{p}\right)
$$

where $P_{p}(\mathrm{~W})$ is the potential power output; $\rho\left(\mathrm{kg} / \mathrm{m}^{3}\right)$ is the density of water; $g\left(\mathrm{~m} / \mathrm{s}^{2}\right)$ is gravitational acceleration; $n_{t}(0.88)$ is the turbine efficiency [40]; $n_{g}(0.96)$ is the generator efficiency [40]; $c(0.60)$ is the conversion factor accounting for environmental flow deduction [69]; $\dot{Q}\left(\mathrm{~m}^{3} / \mathrm{s}\right)$ is the discharge; $H_{p}(\mathrm{~m})$ is the elevation, and $H_{p . u p}(\mathrm{~m})$ is the elevation at the nearest upstream point.

\subsection{Restriction Zones and Selection of Suitable Sites}

The development of small-scale hydropower projects is usually subjected to social and environmental restrictions during the planning, design, construction and operation phase $[20,67,70,71]$. In order to include such constraints in the analysis, exclusion zones were created and applied in order to spatially restrict hydropower availability (Table 3). In particular, the following parameters were taken into consideration:

- Inland water: Water areas with limited flow, such as lakes, wetlands and stagnant waters, un-favouring run-off hydropower plants and therefore were excluded from this analysis.

- Agricultural zones: Water regulation in hydropower plants may affect agricultural practices in the vicinity. In order to avoid conflicts stimulated by problematic and inefficient water management and sustain biodiversity, exclusion zones were applied to all identified croplands.

- Urban built-up areas: Residential areas with intense human activity (cities, towns) and commercial/industrial infrastructure were assigned a $100 \mathrm{~m}$ buffer zone within which hydropower development was restricted in order to avoid technical, economic and social constraints.

- Barren land: Areas with limited water resources and arid land were excluded from this analysis due to unsuitability for hydropower deployment.

- Stream order: According to the hydropower equation presented above, a conversion factor has been taken into consideration in order to account for the environmental flow. In order to ensure sufficient amount of water flow at the hydro plant location, only rivers with Strahler (Strahler number: A numerical measure of branching complexity [72]) stream order greater or equal than three were included in this analysis [9].

Table 3. List of the type and source of restrictions zones used for the technical assessment of small-scale hydropower in Sub-Saharan Africa.

\begin{tabular}{cccc}
\hline Layer & Type & Buffer & Source \\
\hline Inland water & Lakes, Wetlands, Stagnant Waters & - & {$[57]$} \\
\hline Croplands & Cultivated Areas & $200 \mathrm{~m}$ & {$[59]$} \\
\hline Built-Up & Residential Areas & $100 \mathrm{~m}$ & {$[59]$} \\
\hline Protected areas & $\begin{array}{c}\text { Strict Nature Reserves, Wilderness Areas, National Parks, } \\
\text { Natural Monument, Habitat/Species Management, Protected } \\
\text { Landscape, Managed Resource Protected Areas }\end{array}$ & $500 \mathrm{~m}$ & {$[58]$} \\
\hline Barren land & Desert and Inhabitable Areas & - & {$[59]$} \\
\hline Stream order & Confluence of more than three rivers & - & $\begin{array}{c}\text { using } \\
{[73]}\end{array}$ \\
\hline
\end{tabular}

In total, about $45.3 \%$ of the total area in Sub-Saharan Africa was restricted and characterized as un-suitable for hydropower deployment (Figure 6). Western and eastern African regions do have the highest share of restricted land (Table 4), which is explained by the high population density in both regions. 


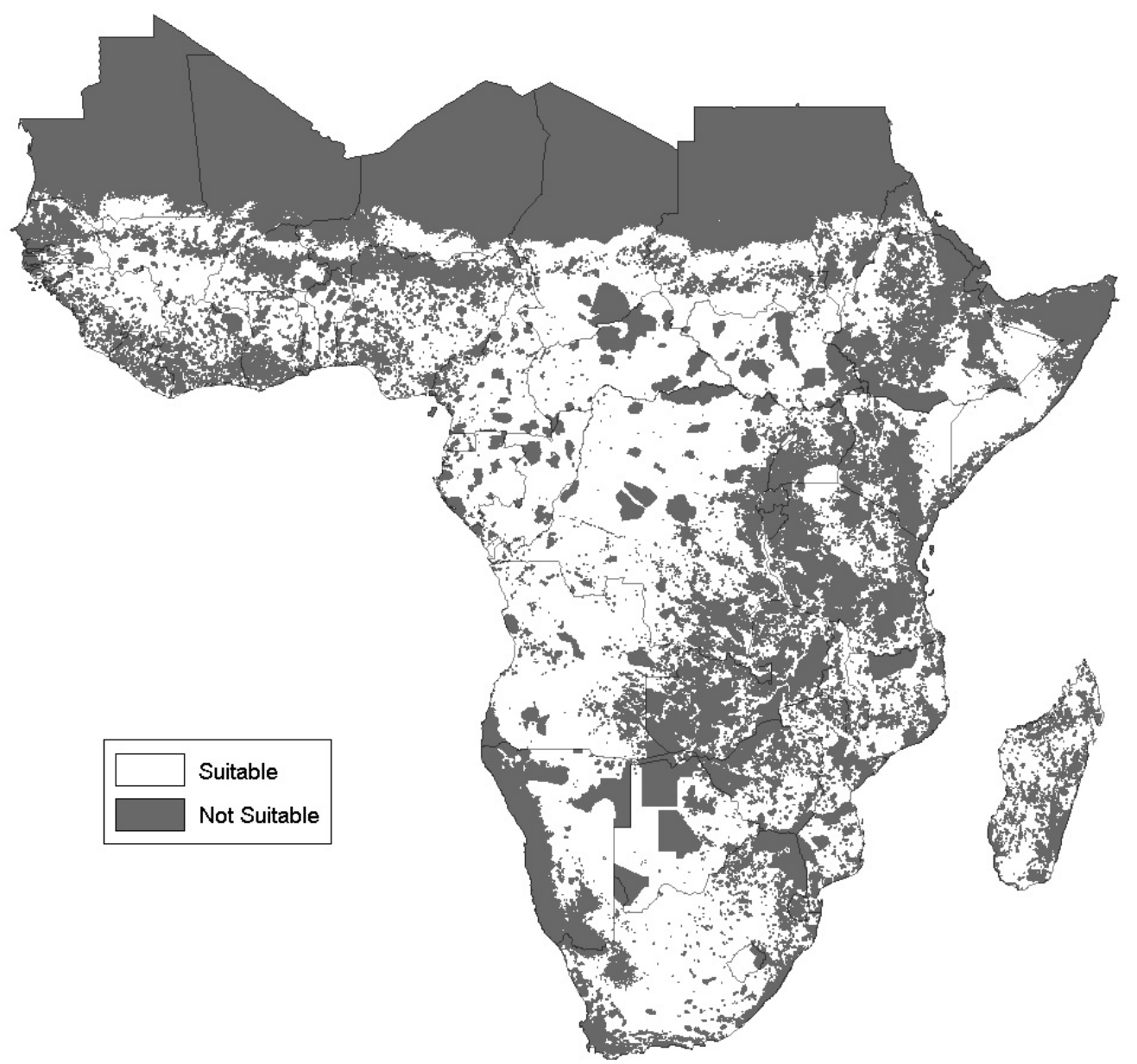

Figure 6. Overall land suitability map for small-scale hydropower deployment in Sub-Saharan Africa.

Table 4. Total vs. restricted land in Sub-Saharan Africa; estimated based on the aforementioned assumptions.

\begin{tabular}{cccc}
\hline Power Pool. & Total Area & Restrictions & Share \\
\hline Name & \multicolumn{2}{c}{$\left(\right.$ Million $\left.\mathbf{~ k m}^{\mathbf{2}}\right)$} & $\mathbf{( \% )}$ \\
\hline Southern Africa Power Pool & 7.5 & 2.6 & 34.7 \\
Western Africa Power Pool & 6.5 & 4.2 & 64.6 \\
Eastern Africa Power Pool & 7 & 3.4 & 48.6 \\
Central Africa Power Pool & 5.5 & 1.8 & 32.7 \\
\hline Total Sub-Saharan Africa & $\mathbf{2 6 . 5}$ & $\mathbf{1 2}$ & $\mathbf{4 5 . 3}$ \\
\hline
\end{tabular}

\section{Results and Visualization}

The results of the hydropower assessment achieved for the defined capacity range (0.1-10 MW) and according to the social and environmental restrictions are mapped in Figure 7. In total 15,599 potential sites were identified across the sub-continent aggregating to a total technical potential of 25,221 MW. 


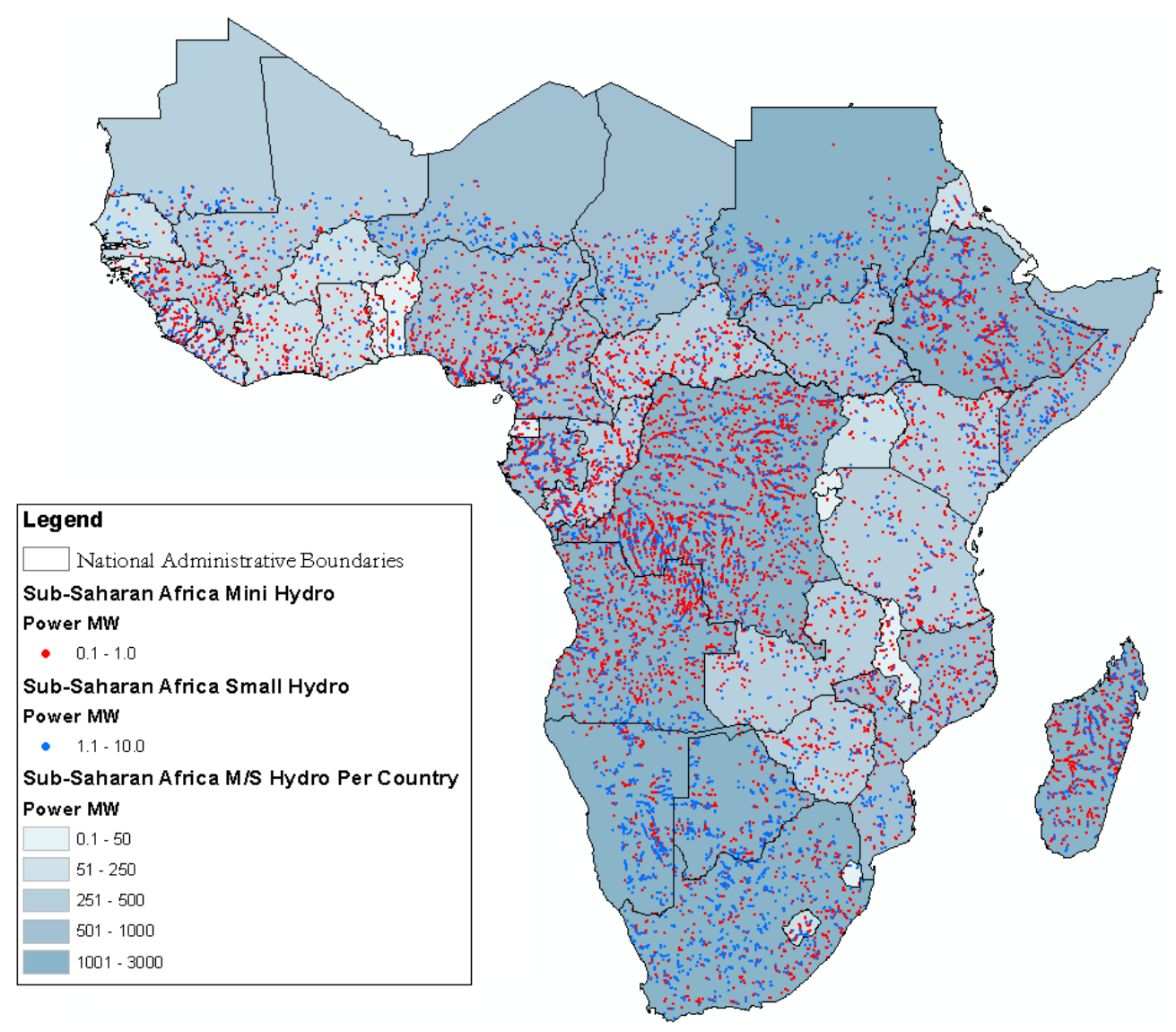

Figure 7. Map illustrating the hydropower potential sites identified for capacities between 0.1 and 10 MW in Sub-Saharan Africa.

Figure 8 presents a categorization of the potential small and mini hydropower results per African power pool. The southern African power pool shows the highest value with an estimated potential capacity of approx. $9.9 \mathrm{GW}$, followed by the central and eastern African power pools showing approx. 5.7 and 5.6 GW respectively. The western Africa power pool shows the lowest potential with approx. $3.9 \mathrm{GW}$.

One explanation of these results may derive from the fact that the total area in the power pools is different, as shown in Table 4. That is, the extent of river network is bigger and therefore more potential sites were identified. On top of that, the impact of restriction zones on the final results should also be denoted. As indicated in Table 4, densely populated areas (e.g., western or eastern Africa) with intense agriculture activities have lost a considerable amount of suitable land for the development of hydropower due to the application of the restriction filters presented in Section 2.6. That obviously affected the identified potential as well; in the western African power pool the final potential was $56.8 \%$ lower than the theoretical potential (no application of restriction zones) as shown in Figure 8. Interestingly, the southern Africa power pool had the lowest loss rate, with $27.5 \%$ of the total identified sites falling within a restricted area; hence excluded. This indicates that the results are quite sensitive to the selection of restriction zones, which need to be selected appropriately so that they reflect the existing social, economic, technical and environmental limitations in each area. 


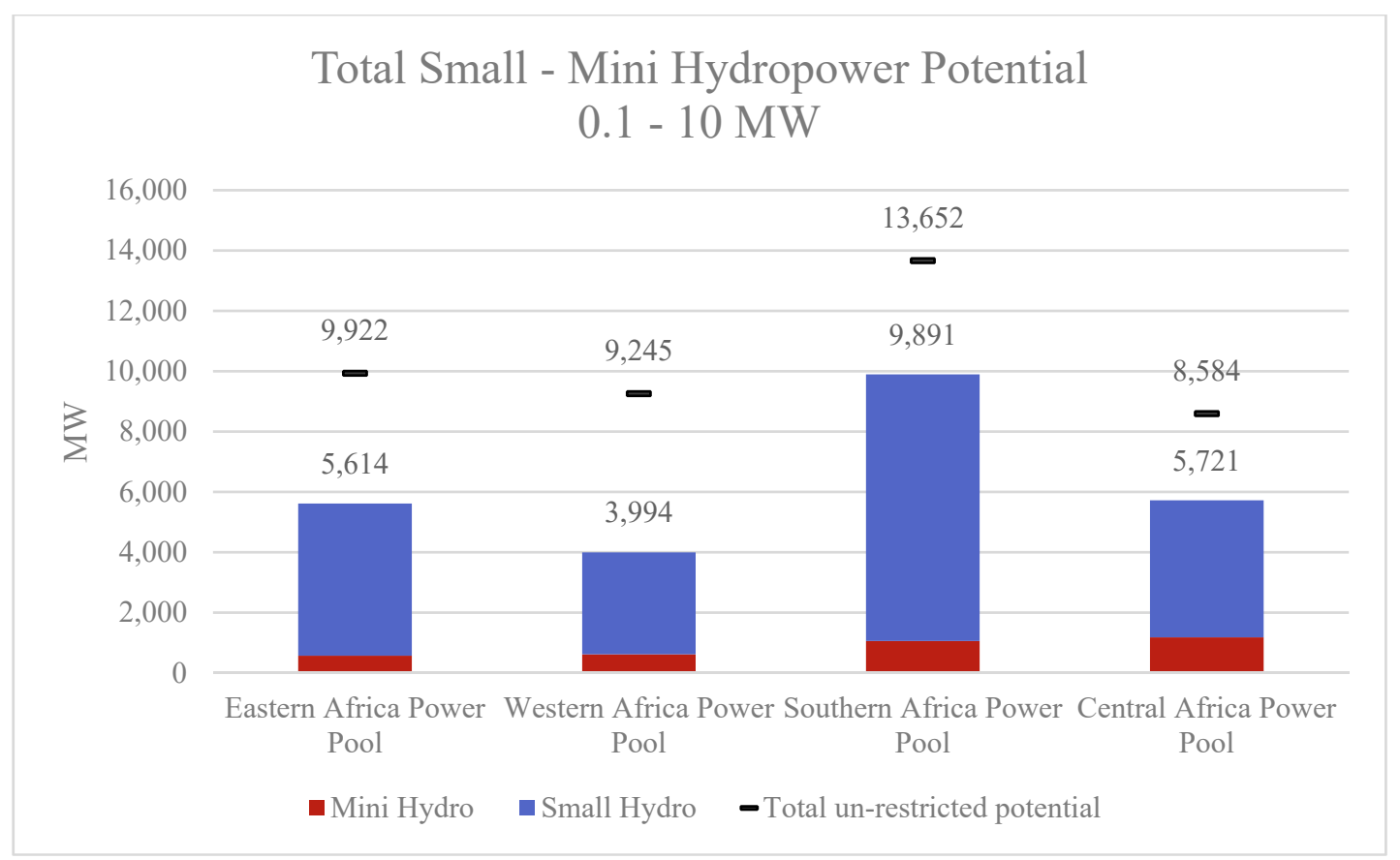

Figure 8. Small-scale hydropower potential per African power pool (detailed description of the countries per power pool is available in Appendix A).

In order to get an alternative look on the results, a hydropower availability index was introduced as shown in Table 5. The index indicates the potential power in terms of $\mathrm{kW}$ per $\mathrm{km}^{2}$ of identified suitable land. The southern part of the sub-continent seems to offer higher availability index for small-scale hydropower deployment with the western, eastern and central parts to follow respectively.

Table 5. Identified small-scale hydropower density per African power pool.

\begin{tabular}{|c|c|c|c|c|c|}
\hline Power Pool & $\begin{array}{l}\text { Natural Mean } \\
\text { Annual Runoff }\end{array}$ & $\begin{array}{l}\text { M/S Hydropower } \\
\text { Sites }\end{array}$ & $\begin{array}{l}\text { M/S Hydropower } \\
\text { Potential }\end{array}$ & Suitable Land & $\begin{array}{c}\text { Small-Scale } \\
\text { Hydropower } \\
\text { Availability Index }\end{array}$ \\
\hline Name & (billion $\mathrm{m}^{3}$ ) & $\#$ & (MW) & (Million km²) & $\left(\mathrm{kW} / \mathrm{km}^{2}\right)$ \\
\hline Southern Africa Power Pool & 1095 & 5356 & 9917 & 4.9 & 2.02 \\
\hline Western Africa Power Pool & 1004 & 2307 & 3884 & 2.3 & 1.69 \\
\hline Eastern Africa Power Pool & 714 & 3188 & 5699 & 3.6 & 1.58 \\
\hline Central Africa Power Pool & 1341 & 5030 & 5721 & 3.7 & 1.55 \\
\hline Total Sub-Saharan Africa & 4785 & 15,881 & 25,221 & 14.5 & 1.74 \\
\hline
\end{tabular}

In addition, the total theoretical mean annual runoff was estimated for each power pool. The values were estimated by aggregating the mean runoff values of all grid cells within the geographic area of each power pool. The central African power pool shows the highest runoff values (Congo river is the boast the biggest discharge volume in Africa [74]). It should be noted that the total natural mean annual runoff value in Sub-Saharan Africa was estimated at 4785 billion $\mathrm{m}^{3}$, about $22 \%$ higher than the value found in the literature (3931 billion $\mathrm{m}^{3}$ [52]). The difference can be attributed to the projection system used in this study (EPSG:3395) which may have inevitably caused some distortion in the calculation of the geographic area.

\subsection{Mini Hydropower Potential}

The total mini hydropower potential (0.1-1 MW) in Sub-Saharan Africa was estimated at 3421 MW. Most of the 10,216 sites identified were located in the central part of the sub-continent, with the Democratic Republic of Congo (DRC) and Angola showing the highest potential reaching 975 MW. On the contrary, no potential site was identified in Djibouti while Burundi, Rwanda, Gambia 
and Swaziland show very little mini hydropower potential. The main reason behind that is the small size of these countries, with short, low stream-order river networks, which in combination with the restriction zones applied did not allow the identification of any potential sites. This does not imply that there is no small-scale hydropower potential in these countries but rather points out the sensitivity of these analyses, especially in regards to the selected restriction zones. Take, for example, the case of Rwanda where approximately $662 \mathrm{~km}$ of river networks have been identified. The assessment yielded about 28.4 MW of small-scale hydropower potential in 29 sites across the country, which however were characterized as un-suitable as they were located within restricted zones, hence excluded from the final results.

\subsection{Small Hydropower Potential}

For small hydropower (1-10 MW) there were 5383 sites identified across the studied countries, with the total estimated potential reaching 21,800 MW. The highest potential is evident in the central corridor of the sub-continent with South Africa, the Democratic Republic of Congo (DRC) and Sudan accounting for approximately one-third of the total potential identified. No potential sites were identified in Burundi, Djibuti, and Rwanda for the same reasons explained in the previous paragraph. Table A2 in Appendix B summarizes the total small-scale hydropower potential per country for all 44 countries included in the assessment.

\section{Discussion}

This study aimed to identify, in a consistent way, suitable locations for the deployment of small-scale hydropower plants per location, country, and region in Sub-Saharan Africa along with their estimated maximum capacity. The results have shown that there is significant potential in the sub-continent whose exploitation could help tackle electricity deficits and secure electricity supply at a local level. The spatial identification and quantification of small-scale hydro potential is expected to be an important addition to the field of spatial electrification planning. In fact, results of this study have already been used to compare various electrification technologies in the Sub-Saharan Africa context $[2,11]$ and feature in online platforms for sustainable development $[75,76]$. Despite that, there is still room for improvement; here are some limitations that we believe should be highlighted.

GIS environments allow the integration of various types of data into a single system. This makes them a powerful tool for multi-perspective analysis over a certain geographic area. However, spatial inaccuracies cannot be entirely avoided due to the nature of the input geospatial data. This study attempted to minimize the sources of error by using up to date, well formatted and documented publicly available data serving the purpose of its objectives. Nevertheless, the combination of datasets with varying spatial or temporal resolutions and geographic projections may have led to compounding inaccuracies and imprecisions, fact that should be taken into account when reading the results.

It should also be highlighted that the results of this analysis aim to serve only as an initial screening of small-scale hydropower availability in the examined region. Further socio-techno-economic analysis is required in order to estimate the extent of their exploitability into viable electrification solutions.

From a technical standpoint and in order to be able to work on a regional level, this assessment was based on a number of generalized assumptions, unable to capture specificities of the locality. Parameters related to the specific hydrological, topological, geological characteristics in each location, as well as technical specifications, are critical elements for the deployment of sustainable hydropower projects and are only partially represented in this study.

From an economic standpoint, the exploitation of hydropower sites highly depends on their economic feasibility. The latter, is consequently dependent on the seasonality of water resources, estimated electricity production, supply chains and technology availability, infrastructure to reach the desired load, power purchase agreements and deployment schemes (e.g., tariffs, taxation) among others [70,77-79]. The average installation costs in the region stand at $3000 \$ / \mathrm{kW}$; capacity factors reach $57 \%$ and generating costs (lcoe) average at $0.06 \$ / \mathrm{kWh}$ [80]. These values make small-scale 
hydro, if available, a reliable and cost effective off-grid electrification option for rural populations in Sub-Saharan Africa as shown in several cases $[2,9,11,25]$. Even though economic feasibility metrics are not covered in this study, we believe that the identification of potential locations is already an important first step towards a more inclusive electrification planning process.

The successful deployment of hydropower is also dependent on the level of compliance with the broader social norms in each location. Social acceptability, legal/geopolitical constraints, water use disputes, respect to local ecosystems etc. are critical elements for the development of successful hydropower projects. Past examples have shown small-scale hydropower can spur further development in the vicinity (e.g., USA [81], China [82], Nepal [83]) if developed sensibly. The provision of reliable and affordable electricity can improve productivity and economic output, allowing for more profit and leading to a socio-economic upgrade of the nearby electrified area (e.g., Tanzania [84]). In addition, the active engagement of local communities in the development, operation and management of their hydropower can create a feeling of ownership which works beneficially for the diligent operation of the system. In parallel, it enhances local technical capacity, which may also have a positive impact on the community. All these issues are only partially (if not at all included) in this assessment.

Finally, from a regulatory standpoint, the development of hydropower projects goes hand-in-hand with existing policy framework in each location. Many African countries have demonstrated their commitment towards the achievements of universal access goals through their national electrification roadmaps [85]. The extent to which small-scale hydropower is part of such plans depends on various factors (e.g., regional agreements, local legislation, financing mechanisms, geo-politics etc.) $[77,79]$. Take for example the case of Western Africa Power Pool, where the long term vision promotes the development of large (>100 MW) hydropower projects; this leaves less priority for small-scale hydropower projects [79]. Policy can strongly impact the level of exploitable small-scale hydro potential in regards to the results of this study and therefore should not be neglected.

It is highly recommended that future developments should take into consideration the aforementioned issues. Future activities should also consider the development of scenarios investigating the effects of other external factors such as climate change (e.g., altering precipitation patterns, extreme droughts, land desertification, population rehabilitation) thus providing a more holistic picture of the long term exploitable hydropower potential in the region.

\section{Conclusions and Final Remarks}

Currently, about $57 \%$ of the population in Sub-Saharan Africa does not have access to electricity [2]. The evident economic development in most of the countries in the region, coupled with the growing population and steadily increasing energy access rates, is expected to push electricity demand levels between $883-1231$ TWh by 2030 [86]. In order to effectively cope with the growing demand, electrification strategies and policies need to be developed and employed in a sustainable manner by securing the smart utilization of all resources available.

Past electrification efforts have shown that decentralized hydropower has been an effective solution for rural electrification, especially when its deployment was the result of structured and well-informed action plans. Similarly, small-scale hydropower can serve as a plausible electrification option in today's electrification challenge. To that end, proper planning is essential and so is new data and tools that can better inform electrification policy.

Despite its limitations, we feel that this study provides a useful set of new information aiming to fill in potential data gaps and construct more inclusive and informative electrification plans in Sub-Saharan Africa. We hope that both the methodology and results of this study will serve as a useful basis for future assessments aiming to support electrification efforts where most needed. Therefore, all data, layers and methods used in this analysis are open and available upon request. In addition, all results are available in Reference [87]. 
Author Contributions: “Conceptualization, A.K.; Methodology, A.K., D.M. and S.H.S.; Software, A.K. and C.A.; Validation, M.H., H.B. and A.D.R.; Formal Analysis, A.K.; Investigation, A.K.; Resources, A.K., H.B. and A.D.R.; Data Curation, A.K.; Writing-Original Draft Preparation, A.K.; Writing-Review \& Editing, A.K., D.M., H.R. and M.B.; Visualization, A.K.; Supervision, H.R., M.B., M.H.; Project Administration, M.H.; Funding Acquisition, M.H.", please turn to the CRediT taxonomy for the term explanation.

Funding: “This research was funded by The Swedish Research Council for Environment, Agricultural Sciences and Spatial Planning under grant 942-2015-1304 and by the Swedish Center for Smart Grids and Energy Storage (SweGRIDS-ABB) under grant VF-2015-0018".

Conflicts of Interest: The authors declare no conflict of interest.

\section{Appendix A}

Table A1. List of countries per Sub-Sahara African power pool [5].

\begin{tabular}{cccc}
\hline $\begin{array}{c}\text { Western Africa } \\
\text { Power Pool }\end{array}$ & $\begin{array}{c}\text { Eastern Africa } \\
\text { Power Pool }\end{array}$ & $\begin{array}{c}\text { Southern Africa } \\
\text { Power Pool }\end{array}$ & $\begin{array}{c}\text { Central Africa } \\
\text { Power Pool }\end{array}$ \\
\hline Benin & Burundi & Angola & Cameroon \\
Burkina Faso & Djibouti & Botswana & Central African Republic \\
Cote d'Ivoire & Eritrea & Lesotho & Chad \\
The Gambia & Ethiopia & Madagascar & Congo \\
Ghana & Kenya & Malawi & Democratic Republic of Congo \\
Guinea & Rwanda & Mozambique & Equatorial Guinea \\
Guinea Bissau & Somalia & Namibia & Gabon \\
Liberia & Sudan & South Africa & \\
Mali & South Sudan & Swaziland & \\
Mauritania & Tanzania & Zambia & \\
Niger & Uganda & Zimbabwe & \\
Nigeria & & & \\
Senegal & & & \\
Sierra Leone & & & \\
Togo & & & \\
\hline
\end{tabular}




\section{Appendix B}

Table A2. Mini and small hydropower technical potential per country for 44 Dub-Sahara African countries.

\begin{tabular}{|c|c|c|c|c|c|c|c|}
\hline \multirow{2}{*}{ Country Name } & \multirow{2}{*}{ Country Code } & \multirow{2}{*}{$\begin{array}{l}\text { Natural Mean Annual } \\
\text { Runoff 999(Billion } \mathrm{m}^{3} \text { ) }\end{array}$} & \multicolumn{2}{|c|}{ Mini Hydro (0.1-1 MW) } & \multicolumn{2}{|c|}{ Small Hydro (1.01-10 MW) } & \multirow{2}{*}{ Total (MW) } \\
\hline & & & Identified Sites (\#) & Potential Power (MW) & Identified Sites (\#) & Potential Power (MW) & \\
\hline Angola & $\mathrm{AO}$ & 269.2 & 931 & 301.6 & 364 & 1330.5 & 1632.1 \\
\hline Benin & $\mathrm{BN}$ & 13.0 & 33 & 11.7 & 10 & 31.8 & 43.5 \\
\hline Botswana & $\mathrm{BC}$ & 4.7 & 159 & 70.4 & 292 & 1218.6 & 1288.9 \\
\hline Burkina Faso & UV & 13.4 & 36 & 13.2 & 42 & 232.9 & 246.1 \\
\hline Burundi & BY & 10.6 & 2 & 0.4 & 0 & 0.0 & 0.4 \\
\hline Cameroon & $\mathrm{CM}$ & 284.9 & 420 & 144.0 & 142 & 459.2 & 603.2 \\
\hline Central African Republic & $\mathrm{CT}$ & 124.5 & 321 & 101.1 & 94 & 287.7 & 388.8 \\
\hline Chad & $\mathrm{CD}$ & 20.7 & 111 & 38.1 & 201 & 910.7 & 948.7 \\
\hline Congo & $\mathrm{CF}$ & 199.2 & 335 & 106.8 & 96 & 335.1 & 441.9 \\
\hline Congo, DRC & CG & 1075.0 & 2129 & 673.4 & 673 & 2122.2 & 2795.6 \\
\hline Cote d'Ivoire & IV & 91.2 & 146 & 50.0 & 34 & 97.4 & 147.3 \\
\hline Djibouti & DJ & 1.3 & 0 & 0.0 & 0 & 0.0 & 0.0 \\
\hline Equatorial Guinea & EK & 31.5 & 30 & 10.9 & 6 & 13.5 & 24.4 \\
\hline Eritrea & ER & 14.9 & 23 & 8.1 & 16 & 42.9 & 51.0 \\
\hline Ethiopia & ET & 314.3 & 840 & 267.5 & 292 & 947.8 & 1215.4 \\
\hline Gabon & GB & 235.2 & 343 & 105.9 & 129 & 412.1 & 518.1 \\
\hline Ghana & GH & 63.9 & 85 & 29.1 & 21 & 100.8 & 129.9 \\
\hline Guinea & GV & 182.5 & 235 & 80.6 & 71 & 235.6 & 316.3 \\
\hline Guinea-Bissau & PU & 15.8 & 12 & 2.9 & 4 & 15.6 & 18.5 \\
\hline Kenya & KE & 73.0 & 211 & 63.1 & 97 & 399.7 & 462.8 \\
\hline Lesotho & LT & 9.8 & 44 & 10.8 & 17 & 60.9 & 71.7 \\
\hline Liberia & LI & 144.9 & 94 & 30.6 & 37 & 114.3 & 144.9 \\
\hline Madagascar & MA & 376.3 & 660 & 210.7 & 224 & 766.4 & 977.1 \\
\hline Malawi & MI & 27.5 & 56 & 15.8 & 12 & 28.2 & 44.0 \\
\hline Mali & ML & 37.8 & 113 & 35.5 & 89 & 413.4 & 448.9 \\
\hline Mauritania & MR & 11.6 & 27 & 10.1 & 66 & 358.2 & 368.2 \\
\hline Mozambique & MZ & 140.6 & 346 & 110.3 & 151 & 578.6 & 688.9 \\
\hline Namibia & WA & 8.0 & 218 & 96.2 & 371 & 1588.9 & 1685.1 \\
\hline Niger & NG & 11.4 & 71 & 27.1 & 167 & 759.6 & 786.7 \\
\hline Nigeria & NI & 286.7 & 476 & 164.7 & 187 & 653.9 & 818.6 \\
\hline Rwanda & RW & 8.7 & 2 & 0.9 & 0 & 0.0 & 0.9 \\
\hline Senegal & SG & 7.5 & 20 & 6.4 & 34 & 153.7 & 160.1 \\
\hline Sierra Leone & SL & 113.2 & 111 & 36.1 & 48 & 166.0 & 202.1 \\
\hline Somalia & $\mathrm{SO}$ & 28.6 & 150 & 50.6 & 141 & 565.9 & 616.5 \\
\hline South Africa & SF & 76.2 & 471 & 165.0 & 583 & 2688.2 & 2853.2 \\
\hline South Sudan & SS & 39.9 & 157 & 52.2 & 125 & 635.9 & 688.1 \\
\hline Sudan & SU & 34.0 & 352 & 123.2 & 435 & 2105.4 & 2228.6 \\
\hline
\end{tabular}


Table A2. Cont

\begin{tabular}{|c|c|c|c|c|c|c|c|}
\hline \multirow{2}{*}{ Country Name } & \multirow{2}{*}{ Country Code } & \multirow{2}{*}{$\begin{array}{l}\text { Natural Mean Annual } \\
\text { Runoff } 999\left(\text { Billion } \mathrm{m}^{3} \text { ) }\right.\end{array}$} & \multicolumn{2}{|c|}{ Mini Hydro (0.1-1 MW) } & \multicolumn{2}{|c|}{ Small Hydro (1.01-10 MW) } & \multirow{2}{*}{ Total (MW) } \\
\hline & & & Identified Sites (\#) & Potential Power (MW) & Identified Sites (\#) & Potential Power (MW) & \\
\hline Swaziland & WZ & 2.4 & 5 & 1.5 & 6 & 35.0 & 36.5 \\
\hline Tanzania & $\mathrm{TZ}$ & 148.2 & 221 & 76.5 & 81 & 309.0 & 385.5 \\
\hline The Gambia & GA & 0.4 & 1 & 0.5 & 3 & 19.0 & 19.5 \\
\hline Togo & TO & 11.2 & 28 & 8.7 & 6 & 24.7 & 33.4 \\
\hline Uganda & UG & 40.8 & 28 & 8.7 & 15 & 41.1 & 49.8 \\
\hline Zambia & $\mathrm{ZA}$ & 140.3 & 204 & 61.3 & 63 & 240.4 & 301.7 \\
\hline Zimbabwe & ZI & 40.6 & 116 & 38.5 & 63 & 299.0 & 337.6 \\
\hline Total & - & 4785 & 10,216 & 3421 & 5383 & 21,800 & 25,221 \\
\hline
\end{tabular}




\section{References}

1. Pachauri, S.; Rao, N.D.; Nagai, Y.; Riahi, K. Access to Modern Energy: Assessment and Outlook for Developing and Emerging Regions; IIASA: Laxenburg, Austria, 2012.

2. The International Energy Agency (IEA). Energy Access Outlook 2017: From Poverty to Prosperity; International Energy Agency: Paris, France, 2017.

3. International Energy Agency; International Renewable Energy Agency; United Nations; World Bank; World Health Organization. Tracking SDG7: The Energy Progress Report 2018; World Bank Group: Washington, DC, USA, 2018.

4. UN Sustainable Development-Knowledge Platform. Available online: https:/ /sustainabledevelopment.un. org/sdg7 (accessed on 17 June 2017).

5. Agency, T.I.E. The World Energy Outlook 2014: Outlook for African Energy to 2040; International Energy Agency: Paris, France, 2014.

6. Hughes, T.P. Networks of Power-Electrification in Western Society, 1880-1930; The John Hopkins University Press: Baltimore, MD, USA, 1983; ISBN 0801846145.

7. Barnes, D.F. Meeting the Challenge of Rural Electrification in Developing Nations: The Experience of Successful Programs; Energy Sector Management Assistance Program (ESMAP): Washington, DC, USA, 2005.

8. Javadi, F.S.; Rismanchi, B.; Sarraf, M.; Afshar, O.; Saidur, R.; Ping, H.W.; Rahim, N.A. Global policy of rural electrification. Renew. Sustain. Energy Rev. 2013, 19, 402-416. [CrossRef]

9. Szabó, S.; Bódis, K.; Huld, T.; Moner-Girona, M. Sustainable energy planning: Leapfrogging the energy poverty gap in Africa. Renew. Sustain. Energy Rev. 2013, 28, 500-509. [CrossRef]

10. Szabó, S.; Bódis, K.; Huld, T.; Moner-Girona, M. Energy solutions in rural Africa: Mapping electrification costs of distributed solar and diesel generation versus grid extension. Environ. Res. Lett. 2011, 6, 34002. [CrossRef]

11. Mentis, D.; Howells, M.; Rogner, H.; Korkovelos, A.; Arderne, C.; Zepeda, E.; Siyal, S.; Taliotis, C.; Bazilian, M.; De Roo, A.; et al. Lighting the World: The first application of an open source, spatial electrification tool (OnSSET) on Sub-Saharan Africa. Environ. Res. Lett. 2017, 12. [CrossRef]

12. Mentis, D.; Andersson, M.; Howells, M.; Rogner, H.; Siyal, S.; Broad, O.; Korkovelos, A.; Bazilian, M. The benefits of geospatial planning in energy access-A case study on Ethiopia. Appl. Geogr. $2016,72$. [CrossRef]

13. Pachauri, S.; van Ruijven, B.J.; Nagai, Y.; Riahi, K.; van Vuuren, D.P.; Brew-Hammond, A.; Nakicenovic, N. Pathways to achieve universal household access to modern energy by 2030. Environ. Res. Lett. 2013, 8, 24015. [CrossRef]

14. Mandelli, S.; Barbieri, J.; Mereu, R.; Colombo, E. Off-grid systems for rural electrification in developing countries: Definitions, classification and a comprehensive literature review. Renew. Sustain. Energy Rev. 2016, 58, 1621-1646. [CrossRef]

15. Greacen, C.; Nsom, S.; Rysankova, D. Scaling Up Access to Electricity; The World Bank: Washington, DC, USA, 2015.

16. International Hydropower Association (IHA). Hydropower Status Report; International Hydropower Association: London, UK, 2018.

17. SciDevNet Africa's Hydropower Future. Available online: https://www.scidev.net/global/energy/datavisualisation/africa-hydropower-future-interactive.html\#introduction (accessed on 23 October 2018).

18. World Resources Institute (WRI). Global Power Plant Database. Available online: http:/ / datasets.wri.org/ dataset/globalpowerplantdatabase (accessed on 23 October 2018).

19. African Development Bank Light up and Power Africa. Available online: https://www.afdb.org/en/ documents / (accessed on 23 October 2018).

20. Zhou, Y.; Hejazi, M.; Smith, S.; Edmonds, J.; Li, H.; Clarke, L.; Calvin, K.; Thomson, A. A comprehensive view of global potential for hydro-generated electricity. Energy Environ. Sci. 2015, 8, 2622-2633. [CrossRef]

21. Liu, H.; Masera, D.; Esser, L. World Small Hydropower Development Report; United Nations Industrial Development Organization: New York, NY, USA; International Center on Small Hydro Power: Hangzhou, China, 2013.

22. Stockholm Environment Institute. Renewable Energy Mini-Grids: An Alternative Approach to Energy Access in Southern Africa; Stockholm Environment Institute: Stockholm, Sweden, 2016. 
23. Yadoo, A.; Cruickshank, H. The role for low carbon electrification technologies in poverty reduction and climate change strategies: A focus on renewable energy mini-grids with case studies in Nepal, Peru and Kenya. Energy Policy 2012, 42, 591-602. [CrossRef]

24. World Small Hydropower Development Report 2016; United Nations Industrial Development Organization: Vienna, Austria; International Center on Small Hydro Power: Hangzhou, China, 2016.

25. The International Renewable Energy Agency (IRENA). Africa 2030: Roadmap for a Renewable Energy Future; IRENA: Bohn, Germany, 2015.

26. Kougias, I.; Szabo, S.; Monforti-Ferrario, F.; Huld, T.; Bodis, K. A methodology for optimization of the complementarity between small-hydropower plants and solar PV systems. Renew. Energy 2016, 87, 1023-1030. [CrossRef]

27. Ebhota, W.S.; Inambao, F.L. Facilitating greater energy access in rural and remote areas of sub-Saharan Africa: Small hydropower. Energy Environ. 2017, 28, 316-329. [CrossRef]

28. Hermann, S.; Miketa, A.; Fichaux, N. Estimating the Renewable Energy Potential in Africa; International Renewable Energy Agency, Abu Dhabi and KTH Royal Institute of Technology: Stockhom, Sweden, 2014.

29. Kaunda, C.S.; Kimambo, C.Z.; Nielsen, T.K. Potential of Small-Scale Hydropower for Electricity Generation in Sub-Saharan Africa. ISRN Renew. Energy 2012, 2012, 132606. [CrossRef]

30. Adu, D.; Zhang, J.; Fang, Y.; Suoming, L.; Darko, R.O. A Case Study of Status and Potential of Small Hydro-Power Plants in Southern African Development Community. Energy Procedia 2017, 141, 352-359. [CrossRef]

31. Kling, H.; Stanzel, P.; Fuchs, M. Regional Assessment of the Hydropower Potential of Rivers in West Africa. Energy Procedia 2016, 97, 286-293. [CrossRef]

32. Klunne, J.W. Small hydropower in Southern Africa-An overview of five countries in the region. J. Energy S. Afr. 2013, 24, 14-33.

33. Klunne, W.J. Barriers to the uptake of small hydropower for rural electrification in Africa. In Proceedings of the 30th ISES Biennial Solar World Congress 2011, Kassel, Germany, 28 August-2 September 2011; Volume 2, pp. 1034-1042.

34. Larentis, D.G.; Collischonn, W.; Olivera, F.; Tucci, C.E.M. Gis-based procedures for hydropower potential spotting. Energy 2010, 35, 4237-4243. [CrossRef]

35. Palomino Cuya, D.G.; Brandimarte, L.; Popescu, I.; Alterach, J.; Peviani, M. A GIS-based assessment of maximum potential hydropower production in La Plata basin under global changes. Renew. Energy 2013, 50, 103-114. [CrossRef]

36. Dudhani, S.; Sinha, A.K.; Inamdar, S.S. Assessment of small hydropower potential using remote sensing data for sustainable development in India. Energy Policy 2006, 34, 3195-3205. [CrossRef]

37. Soulis, K.X.; Manolakos, D.; Anagnostopoulos, J.; Papantonis, D. Development of a geo-information system embedding a spatially distributed hydrological model for the preliminary assessment of the hydropower potential of historical hydro sites in poorly gauged areas. Renew. Energy 2016, 92, 222-232. [CrossRef]

38. Cyr, J.F.; Landry, M.; Gagnon, Y. Methodology for the large-scale assessment of small hydroelectric potential: Application to the Province of New Brunswick (Canada). Renew. Energy 2011, 36, 2940-2950. [CrossRef]

39. Ballance, A.; Stephenson, D.; Chapman, R.; Muller, J. A geographic information systems analysis of hydro power potential in South Africa. J. Hydroinform. 2000, 2, 247-254. [CrossRef]

40. Rojanamon, P.; Chaisomphob, T.; Bureekul, T. Application of geographical information system to site selection of small run-of-river hydropower project by considering engineering/economic/environmental criteria and social impact. Renew. Sustain. Energy Rev. 2009, 13, 2336-2348. [CrossRef]

41. Coskun, H.G.; Alganci, U.; Eris, E.; Agiralioglu, N.; Cigizoglu, H.K.; Yilmaz, L.; Toprak, Z.F. Remote Sensing and GIS Innovation with Hydrologic Modelling for Hydroelectric Power Plant (HPP) in Poorly Gauged Basins. Water Resour. Manag. 2010, 24, 3757-3772. [CrossRef]

42. Yi, C.S.; Lee, J.H.; Shim, M.P. Site location analysis for small hydropower using geo-spatial information system. Renew. Energy 2010, 35, 852-861. [CrossRef]

43. Wali, U.G. Estimating Hydropower Potential of an Ungauged Stream. Int. J. Emerg. Technol. Adv. Eng. 2013, 3, 592-600.

44. Kusre, B.C.; Baruah, D.C.; Bordoloi, P.K.; Patra, S.C. Assessment of hydropower potential using GIS and hydrological modeling technique in Kopili River basin in Assam (India). Appl. Energy 2010, 87, 298-309. [CrossRef] 
45. Bayazıt, Y.; Bakış, R.; Koç, C. An investigation of small scale hydropower plants using the geographic information system. Renew. Sustain. Energy Rev. 2017, 67, 289-294. [CrossRef]

46. Serpoush, B.; Khanian, M.; Shamsai, A. Hydropower plant site spotting using geographic information system and a MATLAB based algorithm. J. Clean. Prod. 2017, 152, 7-16. [CrossRef]

47. Müller, M.F.; Thompson, S.E.; Kelly, M.N. Bridging the information gap: A webGIS tool for rural electrification in data-scarce regions. Appl. Energy 2016, 171, 277-286. [CrossRef]

48. Moya, I.; Gastón, M.; Casajús, L.; Sánchez, D.; Cantero, E.; Togeby, M.; Energianalyse, E.; Jafaru, H.E.; Rahman, A.; Vilar, D.; et al. Africa Power Sector: Planning and prospects for Renewable Energy; The International Renewable Energy Agency: Abu Dhabi, UAE, 2015.

49. Marks, J.; Burles, D.; Ford, M.; Marks, D.; Slater, D. Status Report Update: 2016 A Mid-Term Report on Progress, Achievements and Future Perspectives; European Union Energy Initiative Partnership Dialogue Facility (EUEI PDF): Eschborn, Germany, 2016.

50. GADM Maps and Data: Global Administrative Boundaries. Available online: https://gadm.org/ (accessed on 23 October 2018).

51. Shahin, M. Hydrology and Water Resources of Africa. In Hydrology and Water Resources of Africa; Springer: Dordrecht, The Netherlands, 2002; pp. 1-24.

52. United Nations Environment Programme (UNEP). Africa Water Atlas; United Nations Environment Programme: Nairobi, Kenya, 2010.

53. Lehner, B.; Verdin, K.; Jarvis, A. New Global Hydrography Derived From Spaceborne Elevation Data. Eos Trans. Am. Geophys. Union 2008, 89, 93. [CrossRef]

54. Jarvis, A.; Guevara, E.; Reuter, H.I.; Nelson, A.D. Hole-Filled SRTM for the Globe Version 4, Available from the CGIAR-CSI SRTM 90m Database; CGIAR-CSI: Cali, Colombia, 2008.

55. Beck, H.E.; van Dijk, A.I.J.M.; Miralles, D.G.; de Jeu, R.A.M.; Sampurno Bruijnzeel, L.A.; McVicar, T.R.; Schellekens, J. Global patterns in base flow index and recession based on streamflow observations from 3394 catchments. Water Resour. Res. 2013, 49, 7843-7863. [CrossRef]

56. Beck, H.E.; de Roo, A.; van Dijk, A.I.J.M. Global Maps of Streamflow Characteristics Based on Observations from Several Thousand Catchments. J. Hydrometeorol. 2015, 16, 1478-1501. [CrossRef]

57. NASA Socioeconomic Data and Applications Center (SEDAC) Millennium Ecosystem Assessment: MA Ecosystems. Available online: http://sedac.ciesin.columbia.edu/data/set/ma-ecosystems (accessed on 23 October 2018).

58. UNEP-WCMC and IUCN Protected Planet: The World Database on Protected Areas (WDPA). Available online: https: / / www.protectedplanet.net/c/terms-and-conditions (accessed on 23 October 2018).

59. USGS/Earth Resources Observation and Science (EROS). Center Land Cover Type Yearly L3 Global 0.05Deg CMG, MCD12C1 Courtesy of the NASA Land Processes Distributed Active Archive Center (LP DAAC). Available online: https://lpdaac.usgs.gov/dataset_discovery/modis/modis_products_table/mcd12c1 (accessed on 23 October 2018).

60. Van Der Knijff, J.M.; Younis, J.; De Roo, A.P.J. LISFLOOD: A GIS—Based distributed model for river basin scale water balance and flood simulation. Int. J. Geogr. Inf. Sci. 2010, 24, 189-212. [CrossRef]

61. The Global Runoff Data Centre. GRDC Station Catalogue; Federal Institute of Hydrology (BfG): Koblenz, Germany, 2016.

62. Hennemuth, B.; Bender, S.; Bülow, K.; Dreier, N.; Keup-Thiel, E.; Krüger, O.; Mudersbach, C.; Radermacher, C.; Schoetter, R. Statistical Methods for the Analysis of Simulated and Observed Climate Data Applied in Projects and Institutions Dealing with Climate Change Impact and Adaptation; Climate Service Center (CSC): Hamburg, Germany, 2013.

63. Moriasi, D.N.; Arnold, J.G.; Van Liew, M.W.; Binger, R.L.; Harmel, R.D.; Veith, T.L. Model evaluation guidelines for systematic quantification of accuracy in watershed simulations. Trans. ASABE 2007, 50, 885-900. [CrossRef]

64. International Renewable Energy Agency. Renewable Energy Technologies: Cost Analysis Series; IRENA: Abu Dhabi, UAE, 2012.

65. Weedon, G.P.; Balsamo, G.; Bellouin, N.; Gomes, S.; Best, M.J.; Viterbo, P. The WFDEI meteorological forcing data set: WATCH Forcing Data methodology applied to ERA-Interim reanalysis data. Water Resour. Res. 2014, 50, 7505-7514. [CrossRef] 
66. Hijmans, R.J.; Cameron, S.E.; Parra, J.L.; Jones, P.G.; Jarvis, A. Very high resolution interpolated climate surfaces for global land areas. Int. J. Climatol. 2005, 25, 1965-1978. [CrossRef]

67. International Finance Corporation (IFC). Hydroelectric Power: A Guide for Developers and Investors; International Finance Corporation (IFC): Washington, DC, USA, 2015.

68. Wagner, H.-J.; Mathur, J. Introduction and Status of Hydropower. In Introduction to Hydro Energy Systems. Green Energy and Technology; Introduction to Hydro Energy Systems; Green Energy and Technology Springer: Berlin, Heidelberg, 2011; pp. 1-20.

69. Acreman, M.C.; Dunbar, M.J. Defining environmental river flow requirements-A review. Hydrol. Earth Syst. Sci. 2004, 8, 861-876. [CrossRef]

70. European Small Hydropower Association. How to Develop a Small Hydropower Plant ESHA 2004; ESHA: Brussels, Belgium, 2004.

71. Ebhota, W.; Tabakov, P.Y. Hydropower Potentials and Effects of Poor Manufacturing Infrastructure on Small Hydropower Development in Sub-Saharan Africa. Int. J. Energy Econ. Policy 2017, 7, 60-67.

72. Strahler, A.N. Quantitative analysis of watershed geomorphology. Trans. Am. Geophys. Union 1957, $38,913$. [CrossRef]

73. Hornby, D. RivEX ArcMAP Plugin for River Network Delineations, Version 10.26. Available online: http: / / www.rivex.co.uk/index.html (accessed on 24 July 2016).

74. Partow, H. Water Issues in the Democratic Republic of the Congo Challenges and Opportunities; United Nations Environment Programme (UNEP): Nairobi, Kenya, 2011.

75. UNDESA/UNDP Modelling Tools for Sustainable Development. Available online: https://un-modelling. github.io/electrification-paths-presentation/ (accessed on 10 November 2018).

76. The World Bank Electrification Pathways Web Application. Available online: http://electrification. energydata.info/presentation/ (accessed on 10 November 2018).

77. Scharfetter, B.; Van Dijk, M. Legislation governing the implementation of small-scale hydropower projects for rural electrification in South Africa. J. Energy S. Afr. 2017, 28, 14. [CrossRef]

78. Bonthuys, G.J.; Van Dijk, M.; Bhagwan, J.N. A feasibility and implementation model of small-scale hydropower development for rural electrification in South Africa: A case study of Kwa Madiba SSHP Plant. Water SA 2016, 42, 528. [CrossRef]

79. Idiaghe, L. Legislation on Hydropower Use and Development. Sustain. Hydropower West Afr. 2018, $159-187$. [CrossRef]

80. The International Renewable Energy Agency. Renewable Power Generation Costs in 2017; IRENA: Abu Dhabi, UAE, 2018.

81. Williams, J.C. Otherwise a mere clod: California rural electrification. IEEE Technol. Soc. Mag. 1988, 7 , 13-19, 29. [CrossRef]

82. Jiahua, P.; Li, M.; Xiangyang, W.; Lishuang, W.; Elias, R.J.; Victor, D.G.; Zerriffi, H.; Zhang, C.; Wuyuan, P. Rural Electrification in China 1950-2004: Historical Processes and Key Driving Forces; Center for Environmental Science and Policy at Stanford University: Stanford, CA, USA, 2006.

83. Alam, Q.; Reza, S.; Khurshid-ul-Alam, S.M.; Saleque, K. A Review of Hydropower Projects in Nepal. Energy Procedia 2017, 110, 581-585. [CrossRef]

84. Ahlborg, H.; Sjöstedt, M. Small-scale hydropower in Africa: Socio-technical designs for renewable energy in Tanzanian villages. Energy Res. Soc. Sci. 2015, 5, 20-33. [CrossRef]

85. ESMAP Tracking SDG7 | Progress Towards Sustainable Energy. Available online: https://trackingsdg7. esmap.org/ (accessed on 26 October 2018).

86. Taliotis, C.; Shivakumar, A.; Ramos, E.; Howells, M.; Mentis, D.; Sridharan, V.; Broad, O.; Mofor, L. An indicative analysis of investment opportunities in the African electricity supply sector-Using TEMBA (The Electricity Model Base for Africa). Energy Sustain. Dev. 2016, 31, 50-66. [CrossRef]

87. Korkovelos, A. Sub Saharan Africa-Small and Mini Hydropower Potential. 2016. Available online: https: / / energydata.info/dataset/small-and-mini-hydropower-potential-in-sub-saharan-africa (accessed on 25 October 2018).

(C) 2018 by the authors. Licensee MDPI, Basel, Switzerland. This article is an open access article distributed under the terms and conditions of the Creative Commons Attribution (CC BY) license (http:/ / creativecommons.org/licenses/by/4.0/). 